\title{
Gifts, Reciprocity and Ethically Sound Ethnographic Research A Reflexive Framework
}

\author{
Gosovic, Anna Kirkebæk Johansson
}

Document Version

Accepted author manuscript

Published in:

Journal of Organizational Ethnography

DOI:

10.1108/JOE-02-2019-0011

Publication date:

2020

License

Unspecified

Citation for published version (APA):

Gosovic, A. K. J. (2020). Gifts, Reciprocity and Ethically Sound Ethnographic Research: A Reflexive Framework. Journal of Organizational Ethnography, 9(1), 66-79. https://doi.org/10.1108/JOE-02-2019-0011

Link to publication in CBS Research Portal

\section{General rights}

Copyright and moral rights for the publications made accessible in the public portal are retained by the authors and/or other copyright owners and it is a condition of accessing publications that users recognise and abide by the legal requirements associated with these rights.

Take down policy

If you believe that this document breaches copyright please contact us (research.lib@cbs.dk) providing details, and we will remove access to the work immediately and investigate your claim. 


\title{
Gifts, Reciprocity and Ethically Sound Ethnographic Research: A Reflexive Framework
} Anna Kirkebæk Johansson Gosovic

\author{
Journal article (Accepted manuscript*)
}

\section{Please cite this article as:}

Gosovic, A. K. J. (2019). Gifts, Reciprocity and Ethically Sound Ethnographic Research: A Reflexive Framework. Journal of Organizational Ethnography, 9(1), 66-79. https://doi.org/10.1108/J0E-02-2019-0011

\section{DOI: https://doi.org/10.1108/JOE-02-2019-0011}

This article is [- Emerald Group Publishing and permission has been granted for this version to appear here: https://research.cbs.dk/en/publications/gifts-reciprocity-and-ethically-sound-ethnographic-research-a-ref

Emerald does not grant permission for this article to be further copied/distributed or hosted elsewhere without the express permission from Emerald Group Publishing Limited.

* This version of the article has been accepted for publication and undergone full peer review but has not been through the copyediting, typesetting, pagination and proofreading process, which may lead to differences between this version and the publisher's final version AKA Version of Record. 


\title{
Gifts, reciprocity and ethically sound ethnographic research: a reflexive framework
}

\author{
A tale from the field \\ It is evening. I am sitting in a small restaurant in a charming little town in Central Europe. I have spent the \\ whole day participating in an event sponsored by the biopharmaceutical company that I am currently \\ studying, and now, the doctors (who were speakers at the event) and representatives from the company are \\ gathered to celebrate the successful completion of the day.
}

I have come here as part of an ethnographic study on business ethics in a biopharmaceutical company. For a while, I have been focusing on marketing and sales and the various dilemmas that employees and managers find themselves in during this work. I am excited to have been invited for the dinner and curious to observe and participate in the interactions between the doctors and company representatives.

At the dinner, I end up next to one of the doctors. We sit in the corner of a restaurant that, with its dimmed lights and youthful décor, has managed to hit what I find to be the right balance between cozy and hip. The doctor and I enter an interesting discussion about pharmaceutical marketing ethics over a nice glass of wine while our tuna tartare starters are being served by attractive young waiters. Throughout the night, the mood around the table is pleasant, the people are friendly, the food is amazing, and I am having a genuinely nice time.

So, here I am, an anthropologist, having a great time and toasting my fellow diners with excellent white wine, after which I will return to my hotel room, paid for by the biopharmaceutical company, and the next day get on a plane home with a ticket that is likewise paid for by the company. And it strikes me, white wine in hand, tuna tartare on fork, that while I am here, trying to understand the ethical dilemmas in pharmaceutical marketing, that maybe I should ask myself where the real dilemma lies and who is actually 
a bit too involved with whom. I had come here to understand the relationships of exchange between doctors and the pharmaceutical industry, but what I had not anticipated was to also find a relationship of exchange between myself and those I was studying.

\section{Introduction}

Today, empirical research is increasingly financed by external funds, private companies and other projectbased funding ${ }^{1}$ (cf. Musambira et al., 2012), and ties between researchers and corporations are becoming closer (cf. Wichmann-Hansen and Herrmann, 2017). Within organizational ethnography, not only financial ties but also social ties are often a prerequisite for obtaining access to relevant field sites (cf. Macdonald and Hellgren, 2004). However, one may wonder what such financial and social ties mean for our research practices as organizational ethnographers and for our interactions with and descriptions of the field.

The purpose of this article is to address this question and to develop researchers' understanding and practice of organizational ethnography by expanding the methodological literature on research ethics and the tools used to evaluate research quality. Building on previous literature on ethics and quality in qualitative research, this article introduces a reflexive framework for understanding organizational ethnographers' personal and financial entanglements in the field and the possible impact of such entanglements on our research findings and representation of informants and events. Thus, the article aims to contribute to our understanding of what ethically sound ethnographic research is and how it can be conducted and argues that ethics is a central parameter when evaluating the quality of qualitative research. The framework proposes five key questions that we as organizational ethnographers must ask ourselves during each stage of fieldwork to expose the entanglements between ourselves and those whom we study. The notion of entanglements is based on theory of gift-giving in anthropology, which suggests that gifts - in the broadest sense of the word - contain a social force, urging the receiver to reciprocate. As

\footnotetext{
1 "How is research policy across the OECD organised? Insights from a new policy database". OECD, October 2018, No. 55
} 
organizational ethnographers, I argue, we are entangled in such reciprocal relationships with our fields of study.

The framework presented in this article may be useful for researchers regardless of methodology but will likely be of greater relevance to organizational ethnographers.

\section{Literature review}

Within organizational ethnography, representations, analyses and theorizing are results of continuous interactions between researcher and researched and are not generated solely by the researcher (Michailova et al., 2014, p. 140). Moreover, the main tool for conducting ethnographic research is the researcher herself, and the researcher's personal experiences, history and preferences thus inevitably impact her studies (cf. Edwards and Mauthner, 2012; Macdonald and Hellgren, 2004). Even before the fieldwork commences, the research design and what questions the ethnographer chooses to ask are shaped by her prior knowledge, experiences and emotions (Barney, 2005, p. 280). Therefore, it is essential to understand what experiences and emotions influence the researcher and how she addresses these experiences, both from an ethical perspective and from a quality standpoint.

This article inscribes itself into an important yet limited body of literature on the impacts of the researcher's personal experiences and relationships in the field on the research process and research outcomes. In particular, this article builds on - and aims to contribute to - the literature on research ethics within organizational ethnography and the literature discussing how to assess the quality of qualitative research. The reflexive framework introduced in this article is applicable when conducting organizational ethnography and when evaluating it, as research ethics, I argue, is a central aspect of research quality.

\section{Ethical dilemmas in organizational ethnography}

Within organizational ethnography, scholars have focused on various ethical dilemmas related to the entanglements that arise between the researcher and the field, such as in the representation of research 
participants (Court and Abbas, 2013), and how to write about informants who are also colleagues or perhaps friends (Beech et al., 2009; Natifu, 2016; see also Eriksson, 2013). Moreover, several studies have highlighted that loyalty towards the field context may sometimes prevent the researcher from carrying out critical research (Järventie-Thesleff et al., 2016; see also Malm, 2018), have described how prospects of future collaboration may influence data generation and research findings (Macdonald and Hellgren, 2004), and have emphasized the dilemmas that ensue when conducting research as a practitioner (Bell and Nutt, 2012). However, the process of how loyalty is created is still rarely addressed, perhaps due to the prevailing rarity of accounting for one's emotions as a researcher (cf. Anteby, 2013; Gilmore and Kenny, 2015; Michailova et al., 2014; Vincett, 2018).

Related to the question of loyalty is the ethical question of how we as researchers recompense the field after having been allowed to study it (Bernard, 2011, p. 157). Some scholars have discussed the advantages and disadvantages of monetary payments (Head, 2009), and some have detailed using their work and assistance with practical tasks in the field as repayment (see e.g. Srivastava, 1992, p. 18). Other scholars have suggested employing "the intentional ethics of reciprocation" (Murphy and Dingwall, 2001, p. 344; Swartz, 2011, p. 49), which is the ethical standpoint that one's research itself should be beneficial to participants. Contrary to this active intention that research participants should benefit from our research, I argue, are the unintended and perhaps unacknowledged ways organizational ethnographers make recompense to the field, which may impact research quality. This article is devoted to exploring these issues.

\section{Qualitative research and research quality}

Conducting ethically sound research is one aspect of conducting high-quality research, and - in my view - it is impossible to have one without the other. However, unlike quantitative research, qualitative research does not have a well-established framework for assessing quality (Amis and Silk, 2008; Pratt, 2009; Symon et al., 2018; Welch and Piekkari, 2017). What constitutes quality in qualitative research continues to be 
discussed (see e.g. a recent special issue on "good" qualitative research: deGama et al., 2019), but significant contributions have been made towards establishing such frameworks.

Some scholars call for or have sought to establish formulas for assessing qualitative research quality according to a fixed set of standards (see e.g. Bansal and Corley, 2012; Pratt, 2009; Tracy, 2012, 2010). However, frameworks for conducting qualitative research, such as what is known as "the Gioia methodology", originally outlined by Gioia and Chittipeddi (1991), are often (mis)understood as fixed recipes for rigorous research (for a critique of how their framework has been used, see Gioia et al., 2012). Other scholars argue that research should be evaluated according to what types of knowledge the researcher seeks to obtain (Flyvbjerg, 2001, p. 61). Symon et al. (2018) note that unlike the philosophical consensus existing within quantitative research, there is wide range of philosophical positions relative to qualitative research, and therefore, they argue, it may be useful to have different assessment criteria for different epistemologies (Symon et al., 2018, pp. 136-137,143).

Welch and Piekkari (2017) emphasize validity as a relevant quality criterion but argue that the approach to assessing validity should be 'pluralist' and 'context-dependent', meaning it should be transparent about methodological choices, assess the appropriateness of these choices for a particular research setting and evaluate analytical interpretations against the context in which the qualitative data were generated (Welch and Piekkari, 2017, pp. 721-722). Likewise, Symon et al. (2018, p. 146) argue that homogenous and standardized evaluation criteria are inappropriate for assessing the quality of qualitative research and call for more context-sensitive criteria.

Piekkari and Tietze (2016) mention reflexivity as a relevant quality criterion, and, quoting Hardy et al. (2001, p. 554), they write that "reflexive knowledge is situated and includes a recognition of the multiple translation strategies that bring it into being" (Piekkari and Tietze, 2016, p. 230). Following Piekkari and Tietze and others before them (cf. Alvesson and Sköldberg, 2000), I argue that reflexivity is a highly relevant quality criterion for organizational ethnography. In this article, I introduce a reflexive framework to operationalize this criterion. I am not suggesting that this is the only relevant framework for assessing 
quality but rather argue that if applied, it will shed light on an important aspect of research quality. As Koning and Ooi (2013) argue, more reflections on and writings about the awkward encounters and embarrassing emotions experienced during ethnographic fieldwork are needed to increase research quality (see also Donnelly et al., 2013; Michailova et al., 2014), and this article offers one approach to accounting for such awkward encounters. In the remainder of the article, I will emphasize the "gifts" in various forms that we as organizational ethnographers willingly receive from our field sites and point to the inherent social obligation to reciprocate. In doing so, I question the illusion of independent research by highlighting the indebted relationship that we enter with our fields.

\section{Empirical material and methods}

The empirical material forming the foundation for this article was generated through ethnographic fieldwork conducted in 2017 within one multinational biopharmaceutical company. Throughout the research, I have been affiliated with 'The Global Ethics Office', a corporate function focused on ensuring adherence to ethical principles within the organization. This affiliation has been part of a PhD project in organization and management studies aiming to explore how a corporate ethics program is interpreted and enacted when introduced into different national contexts and various professional communities. I conducted fieldwork, consisting primarily of participant observation and interviews, for one year in the company. The empirical material presented in this article was generated throughout these activities and consists of fieldnotes about my own relations to the field and about my positioning, role and actions within it.

\section{Analysis through a reflexive framework}

[TABLE TO BE INSERTED HERE] 
In the following, I draw on my own experiences as an organizational ethnographer to develop the framework outlined in table 1 consisting of five key questions that we must ask ourselves in order to explore the reciprocal relationships that we inevitably enter when conducting ethnographic research.

\section{Question 1: How am I entangled?}

The first element that must be explored is how we as organizational ethnographers are entangled with our fields of study. This question relates to the more structural elements of the engagement and, e.g., whether we are connected via a legal contract regarding the scope, content or limits of the research; publication approval or non-disclosure; the conditions for funding; or - as in my case - employment in the field of study.

In the research forming the basis for this article, I am entangled in several ways. The study is conducted under a funding scheme wherein I, as a PhD scholar, am jointly financed by a company and by a Danish government fund. Within this scheme, the researcher is hired by a private company to carry out a PhD project on a topic deemed useful for the company and relevant from an academic perspective. As a researcher, I have a legal affiliation with the company by virtue of a job contract and am financially dependent on the company, which pays my monthly salary. I also have an obligation to adhere to academic standards of quality and integrity by virtue of my enrollment in a doctoral program, but in this article, I will focus on the obligations created within the field under empirical scrutiny. The topic of my PhD project is business ethics, and the empirical point of inquiry is the company's ethics program (see e.g. Kaptein, 2015), consisting of a code of ethics and various training and awareness activities. As mentioned earlier, throughout the research, I have been organizationally affiliated with one department, and the company funding the research is thus simultaneously the case company for my ethnographic inquiries. In short, my entanglement is tangible, as I have entered a contractual relationship with the field and have a financial dependency on it. 


\section{Question 2: With whom am I entangled?}

The second question that I urge organizational ethnographers to explore is with whom we are entangled. Formal and informal written agreements or legal documents constitute one element, but the people with whom we are entangled constitute another dimension, and we can be as much entangled in a setting without formal arrangements as we are in one with legal ties.

Many ethnographers gain access to relevant field sites via their network (Macdonald and Hellgren, 2004). Due to their legal status, liability and, perhaps, concerns about exposing themselves to researchers, corporate contexts are often less accessible than other types of field sites. Therefore, ethnographers often rely on networks of acquaintances, friends, colleagues or family members to gain access to them. However, after drawing on their network and asking an acquaintance to vouch for them, I argue, few people would not keep this favor in mind when conducting their research. Therefore, we should ask ourselves the following questions: Who has helped us make the research happen? Who has facilitated our access? Who has paved the way for us? To whom am I grateful? On whom do I depend?

In my research, I gained access via official channels by contacting the company. However, as noted by Marschan-Piekkari et al. (2004), access is a continuous endeavor, and gaining official access to a company does not necessarily mean gaining access to all departments or subsidiaries. Indeed, I have had key gatekeepers who have paved the way for my access internally.

Another aspect of entanglement is the ethnographer's relations with people in the field once access has been granted. When spending as much time with people as ethnographic fieldwork requires, the ethnographer inevitably becomes closer to people's lives as a whole. As a result, many ethnographers develop what Macdonald and Hellgren (2004, p. 268) term "the hostage syndrome" and start identifying with the interests of their interviewees. Therefore, it is important as a research to ask questions such as "Is 
there anyone that I particularly care about in the field? Are there people who have become important to me or that I have taken a particular liking to?"

Within my fieldwork in the office setting, I have a desk next to my research subjects. Most days, we eat lunch together, and besides being my research subjects, they also feel like my colleagues (which, formally, they actually are due to my employment in the company). I know the names of their children, I have followed construction projects on their private homes and I have grown to appreciate their company quite a bit. Of course, the eternal balancing act in ethnographic fieldwork is to establish such relationships, often called rapport or complicity (Marcus, 1997), while maintaining a critical, analytical distance. In order to succeed in maintaining this balance, we need to carefully scrutinize these relationships.

\section{Question 3: What is the nature of the gifts that I receive?}

The third question that I urge ethnographers to explore is the nature of the gifts that we receive from the fields that we study. To understand the importance of this consideration, it is helpful to return to French sociologist and anthropologist Marcel Mauss and his social scientific classic, The Gift: Forms and Functions of Exchange in Archaic Societies (Mauss, 2000), first published in 1924. Mauss describes the social processes surrounding gift-giving and non-economic rational exchange, and his analysis is based on ethnographic descriptions from Polynesia, Melanesia and Northwestern America, based on which he traces the social rules surrounding exchange and gift giving and describes how the circulation of gifts, favors, rituals, etc., take an almost voluntary form and play an important role in preventing war and quarrels (Mauss, 2000, p. 18). Moreover, such exchange takes place not only between individuals but also between entire tribes, clans and families. The purpose of gift exchange, Mauss argues, is not so much the redistribution of resources or exchange of goods but rather the creation and maintenance of relationships (Heins et al., 2018, p. 128). These relationships are forged through gifts, as - according to Mauss - any gift will carry with it a social force that obliges the receiver to reciprocate. 
A gift is not neutral, Mauss writes, as the giver gains power over the receiver through the gift, and the receiver allows herself to enter this relationship of debt by accepting the gift (Mauss, 2000, pp. 24-25,61). Moreover, unlike other types of commodity exchange, gift-giving is asynchronous, and the counter gift is thus not expected immediately; moreover, the exchange does not have a predefined currency (Heins et al., 2018, p. 128).

Thus, the things that are exchanged are never liberated completely from those who exchange them, and thereby, a social bond is created between the two (Mauss, 2000, p. 51). As noted by Heins et al. (2018, p. 128), Mauss's theory of the gift represents a distancing from dichotomist notions of gifts as expressions of either free will or obligation; generosity or self-interest.

Returning to the context of organizational ethnography, a similar urge to repay the communities we study is activated by the gifts that we receive from our fields, and it is thus essential to explore the nature of these gifts. As gifts take various forms, it can be useful to ask the following questions: What are the things that I appreciate about my fieldwork? What elements of my fieldwork make me feel privileged? How am I being treated and how does that make me feel? How are my informants and gatekeepers helping me? What is the value of the knowledge that I gain from being here?

In short, it is important to reflect on all the gestures, helping hands, opened doors, etc., that are offered during fieldwork. To illustrate the diverse nature of such gifts, in the following, I invite the reader to observe two types of gifts that I received during my own fieldwork, the latter less tangible than the first but valuable nonetheless.

Money, benefits and perks

My annual salary before tax as a PhD fellow within this company is 444,000 Danish Kroner (approximately 60,000 EUR). Approximately half of this amount is reimbursed by the aforementioned government fund, 
but the company is still left with an annual bill of approximately 30,000 EUR for my work, of which I receive approximately $60 \%$ due to the Danish tax rates. Moreover, the PhD project involves various trips to subsidiaries and events abroad, most of which are likewise paid for by the company. Of course, as described earlier, the project has been shaped according to the needs of the company, and the salary and the travel funds could thus be considered a natural part of this employment. However, doing a PhD project had been a dream of mine long before I entered the company, and getting a salary for a dream come true makes me feel that my salary is more of a privilege than a fair and well-earned reward. Moreover, as a PhD fellow, I also have an obligation to cater to the academic community and to do work not necessarily directly applicable to or useful for the company (the present article being one example), which strengthens my sense of privilege. As Mauss (2000) noted, gifts can take the shape of material objects or of rituals, favors and the like, and the salary I receive, I would argue, meets this description precisely because it often feels like a gift.

In addition to my monthly salary, the company has taken me in and provides me with perks as they would with any other employee. For Christmas last year, all the employees received large Christmas presents, and I recently attended the annual summer party, which, compared to my prior experience as an employee in the public sector, was a rather lavish event. I have gathered from acquaintances in the private sector that generous Christmas presents and parties are fairly common, and the social exchange literature on compensation and benefits within the human resources (HR) realm explains that such elements are part of the HR toolbox for retaining employees and showing appreciation (see e.g. Rhoades and Eisenberger, 2002). However, as researchers, we need to ask ourselves what the consequences might be of being exposed to the same HR tools that are intended to retain regular employees and create loyalty towards the organization under study.

Access to events and people's time 
As Mauss (2000) described, gifts are not always tangible things such as salaries or Christmas presents.

Rather, within organizational ethnography, the gifts that researchers receive most often come in the shape of access to activities, events, and internal documents and especially people's time.

When I arrived at the biopharmaceutical company, a thorough introduction program was arranged for me that included personal meetings with representatives from every major corporate function. Later in the study, I was seeking access to Research \& Development and Marketing \& Sales, and I had expected to encounter some difficulties in obtaining it. However, access was granted to me quickly, and without any reservations, I obtained permission to follow sales representatives on their sales visits and to follow two project groups in charge of managing the testing of new pharmaceuticals on humans. Only after having spent some time in the academic community did I realize the value of this "gift" - the ease of access - and the difficulties faced by many other researchers in gaining such access to companies and their employees.

\section{Question 4: How do I reciprocate?}

As argued by Mauss (2000), by giving a gift, the giver gains power over the receiver, who in turn allows this unequal power relation to be established. Moreover, the gift urges the receiver to reciprocate. As is the case with gifts, the counter gifts that ethnographers offer in return can also take a variety of forms.

The fact that I am paid and that this payment feels like a gift, as well as the fact that I receive Christmas presents, invitations to summer parties, etc., does not obligate me to reciprocate with similar objects or benefits. However, I have realized that I do appreciate these gestures and that they do make me feel that the company cares for its employees, consistent with the intention behind such HR tools. Moreover, I have grown increasingly fond of the company and recently realized that I would actually like to stay here beyond my PhD contract. Of course, this is not only because of the presents but also because of the colleagues, the interesting work that they do and all the other factors that influence such a decision. Regardless, somehow, 
the company has managed to gain my loyalty (cf. Macdonald and Hellgren, 2004), and I wonder if this loyalty has somehow grown out of all the various gifts I receive.

As mentioned before, in my fieldwork, I have been provided with an office space, and my key informants are almost like colleagues. Other informants from other departments have likewise taken me in, and some of them have spent numerous hours explaining their work to me. As mentioned earlier, the access I have been granted in the company to people, documents, events and meetings has been extraordinary, and I have found myself amazed at others' openness and willingness to spend time on me. However, this amazement at people's kindness has also on several occasions influenced how I write. Numerous times, I have found myself reflecting on how I represent my informants, how my descriptions make them look and if they would be offended when reading these descriptions. Most often, my concerns are connected to how my informants would look to colleagues from other departments should they read my writings. For example, one of my informants has a rather direct way of speaking. By now, I have gotten to know him and grown to appreciate him and the many hours he has spent on me. Moreover, he has been a central gatekeeper in allowing me access to various people and contexts in the company. Recently, when writing up another article, I found myself selecting more moderate statements to illustrate his points when selecting quotations for inclusion in the paper.

For example, one of the reoccurring themes in our conversations was the difficulties that he encountered when conveying a policy to countries outside of his Scandinavian home context. We discussed this several times, and while he recognized that the policy was not very concrete, he remained frustrated about the difficulties of persuading people to accept his approach. When writing up this theme in an article, I decided to present the point that he was trying to make throughout all of our discussions rather than inserting the few, more colorful quotations that may have given the reader the impression that he was less nuanced than he actually was. For example, I left out quotations such as "...Some people don't have the capacity to think for themselves. And there are also many cultures where you are not asked to think for yourself. You 
have been brought up to do as you are told". Instead, I chose to describe his experienced difficulties as follows: "He admits that this approach is much more abstract and repeats that it requires people to 'use their head' and 'think for themselves' (...) And the idea of the ability to think for yourself could be seen as a cultural reference to the aforementioned ideal of critical thinking running through Scandinavia's educational system (...) Moreover, the rhetoric surrounding this ideal of being able to 'think for yourself' and 'use your head' likewise underscores a valuation and legitimization of this particular approach and, perhaps, a devaluation of other approaches".

Thus, the somewhat harsh statement about some people's lack of capacity to think for themselves that expressed assumptions about other cultures as producing individuals unable to think independently was left out in favor of a description that better captured the content of the entire discussion, namely, that the informant was aware that the policy in question was somewhat abstract and therefore not easily applied across the entire global organization. Moreover, I described that his rhetoric indicates a devaluation of approaches other than his own and thus remained critical but without using the quotation about other people's lack of capacity to think for themselves, which might have been impactful but did not represent the entirety of our discussions. As Gusterson (1997) writes, we always have an obligation to guard the identity of our informants and reflect on how we portray them, but this obligation becomes more explicit when people's careers are at stake. In this case, it was not one particular employee that needed protection, as I made sure to thoroughly anonymize individual participants; rather, I risked making this employee's department look bad in the eyes of other departments if I used his more direct comments. Moreover, he has shared much more with me than I believe most people would, and in the process of acquainting ourselves with one another, we have built what I feel to be a trusting relationship. Therefore, I did not want to betray his trust by representing his department in an unflattering way through the selection only of statements of a harsh nature (cf. Beech et al., 2009) when more moderate statements expressing the same points were available. 
However, I still ask myself if I should have chosen differently, as I am sure that this intentional omission of certain statements was a result of the relationship I had built with him and the gratitude I felt towards him. I simply felt that I owed it to him to represent him by what he meant rather than by the catchy but harsh statements with which he sometimes expressed his opinions. This feeling of debt, I would argue, is a result of the gifts that I received from him, which urged me to reciprocate.

On the other hand, perhaps the gifts that we receive and the obligations they create for us to reciprocate actually counter the temptation to write up our analyses with sharp edges. Sometimes, harsh statements can make an analysis stand out more clearly, and it is certainly tempting to select such statements to underscore a point in an article. However, I believe that, as researchers, we should balance the need to convey clear messages to our research communities with adherence to the nuances experienced in the field. As emphasized by Michailova et al. (2014, p. 151,153), if a researcher is overly embedded in her ethnographic context, there is a risk that she may become what they term 'a captive of the field', which prevents her from maintaining the emotional and mental disengagement required to reflect critically upon that field. However, emotional engagement may also have productive outcomes that increase the quality of written accounts from the field, as it obliges the researcher to consider her representations more thoroughly, as exemplified above.

The more specific questions one should ask oneself depend on the context under study, but the questions that have been helpful within my fieldwork and that may resonate with organizational ethnography more broadly are as follows: Do I steer my research towards questions that my field is interested in? Do I refrain from asking certain questions that could have been relevant? Do I represent informants and contexts in a particularly friendly/unfriendly light? Do I leave out compromising content when I write up my analysis? Do I refrain from theoretical framings that could have been productive? Do my entanglements make me less prone to cherry picking and more thorough about selecting examples? 
There may be many reasons why the answer to any of these questions could be 'yes', but if we have indeed made certain choices because of our reciprocal relationships in the field, it is important to reflect on and be aware of these and disclose them to our communities.

\section{Question 5: For how long am I entangled?}

The last element of the proposed framework involves reflection on what happens after the fieldwork. As noted by Michailova et al. (2014), exiting the field is as much a continuous and negotiated process as gaining access to it, and theorizing is greatly influenced by the relationships with the field that continue after the researcher has completed her fieldwork (Michailova et al., 2014, p. 139). Moreover, many scholars continue returning to their fields for other projects or further insights for considerable periods of time. In these cases, it is relevant to reflect upon the ways in which prospects or hopes for future collaborations impact our conclusions and if such hopes and prospects blur our critical gaze or make us refrain from analyses that will not be appreciated in our field sites. It may therefore be relevant to ask ourselves whether we will (or hope to) have a relationship with the field upon completion of the fieldwork and, if so, if that wish has an impact on how we conduct our analyses and represent our fields.

Within my field site, I have been given hints of a possible future in the company. I find this potential future employment attractive but wonder what the consequences of this attraction might be and if it poses a risk to my research integrity, as it represents yet another (intangible) gift. As with the other gifts described earlier, there is a risk of reciprocating the possibility of future employment with self-censorship in the analytical process which. Such a risk, I argue, requires continuous reflexivity about how I theorize, what I leave out of an analysis and why. As argued by Macdonald and Hellgren (2004), anyone would likely be less willing to be critical, even if unintentionally, towards a possible future employer than towards a field to which one does not aspire to return. Therefore, I believe, the most viable way to mitigate this risk of selfcensoring when presented with the option of future research funding, continued collaboration or future 
employment is to be aware of this risk and maintain a continuous reflexivity about the choices we make in the analytical process and when presenting our research. I wish to emphasize that I do not find the desire for a continued relationship with the field to be problematic in itself. In fact, I would argue that being forced to consider whether or not our field would welcome us - or any member of our research communities - back after reading how we represent them promotes healthy reflection that should be part of any fieldwork, regardless of our closeness to or distance from the field after completion of the study.

\section{Discussion and Conclusion}

Within this article, I have argued that research ethics is a central consideration for evaluating research quality. To operationalize this assertion, I have introduced a framework for organizational ethnographers to reflect upon their entanglements with their fields of study and the possible impacts of these entanglements. Drawing on anthropological theory on gift-giving and reciprocity, the framework consists of five central questions that we as ethnographers must ask ourselves, reflect upon and be transparent about as an essential step in the quality assessment of research by ourselves and others.

As I have shown, in my fieldwork, the gifts that I received from the field urged me to reciprocate. Although my position as an employee in the field may be unique, many of us receive similar gifts with similar entanglements as part of our research in organizational settings. However, even without such reciprocal relationships urging us to do so, I find it healthy to reflect on how we make our informants look and if we properly represent what they intended to convey during an entire interview or maybe across several interviews rather than what they just happened to say at one moment in a perhaps catchy but unflattering way. We owe it to our informants to consider how we represent them and the possible negative impact of such representations on them and their careers, departments and companies, despite the possible positive impact on our own research careers and publications. Moreover, the risk of our informants feeling misrepresented or even betrayed is not just a personal matter between us and our informants but is just as 
much a question for the entire research community. In this article, I have emphasized field access as a gift because of the difficulty often encountered by organizational ethnographers in gaining such access and the gratitude we feel when it is granted. If our choices regarding the representation of our informants breach the trust that led to this access, this might impact others' opportunities to gain access in the future. Of course, representation and collateral damage should be ethical concerns in any research, but such ethical considerations are, as I have demonstrated in this article, positively enforced by the obligations inherent in the gift. However, it is also essential to consider when we are in fact adhering to ethical standards and when we are perhaps obeying the bidding of a gift that urges us to reciprocate beyond such standards. As argued by Mauss, disentangling oneself from the social forces of a gift is almost impossible, and despite reflecting upon my field relations and even while writing this article, I cannot release myself completely from the obligation to reciprocate, even while being aware of it. In my case, however, these social forces of the gift have reinforced the ethical standards of nuanced and contextualized field descriptions that I wish to adhere to. However, I will have to remain reflexive in future writings - especially if the possible future in the company becomes a reality - about what the gift may urge me to write or not to write. Thus, I would argue that an important exercise for organizational ethnographers is to bring those gifts that we receive in various forms during research into the light and reflect upon what the consequences might be of having received them for our analyses and findings and the ways we communicate them. One way to do so is by using the framework presented here.

The contribution of this article is twofold. First, by introducing Mauss's perspectives on gift-giving and reciprocity, it emphasizes our entanglements and thereby reveals that the notion of independent research is a mere illusion. Second, it contributes to expanding theoretical and practical understandings of research ethics as one parameter for assessing the quality of qualitative research. By introducing a framework for reflection, it contributes to defining how we might conduct ethically sound ethnographic research and evaluate the quality thereof. The insights presented in this article contribute to a relatively limited body of 
literature within organizational ethnography on the impact of the researcher's personal experiences and relationships on the process and outcome of her research. Such accounts of awkward encounters during fieldwork are scarce but, I would argue, are important for us as researchers to reflect upon and share as part of conducting and assessing ethically sound, high-quality research. Therefore, I would urge the community to be more open and include such reflections in future writings. 


\section{Literature}

Alvesson, M. and Sköldberg, K. (2000), Reflexive Methodology: New Vistas for Qualitative Research, Sage Publications, London.

Amis, J.M. and Silk, M.L. (2008), "The Philosophy and Politics of Quality in Qualitative Organizational Research", Organizational Research Methods, Vol. 11 No. 3, pp. 456-480.

Anteby, M. (2013), “PERSPECTIVE — Relaxing the Taboo on Telling Our Own Stories: Upholding Professional Distance and Personal Involvement", Organization Science, Vol. 24 No. 4, pp. 1277-1290.

Bansal, P. and Corley, K. (2012), “From the editors: Publishing in \&quot;AMJ\&quot; - Part 7: What's different about qualitative research?", The Academy of Management Journal, Vol. 55 No. 3, pp. 509513.

Barney, J.B. (2005), "Where does inequality come from? The personal and intellectual roots of resourcebased theory", in Smith, K.G. and Hitt, M.A. (Eds.), Great Minds in Management: The Process of Theory Development, Oxford University Press, New York, pp. 280-303.

Beech, N., Hibbert, P., MacIntosh, R. and McInnes, P. (2009), “'But I thought we were friends?' Life cycles and research relationships", in Sierk, Y., Yanow, D., Wels, H. and Kamsteeg, F. (Eds.), Organizational Ethnography: Studying the Complexity of Everyday Life, Sage Publications Ltd, London.

Bell, L. and Nutt, L. (2012), “Divided Loyalties, Divided Expectations: Research Ethics, Professional and Occupational Responsibilities", in Miller, T., Birch, M., Mauthner, M. and Jessop, J. (Eds.), Ethics in Qualitative Research, 2nd ed., SAGE Publications Ltd, London, pp. 76-93.

Bernard, H.R. (2011), Research Methods in Anthropology: Qualitative and Quantitative Approaches, 5. ed., Altamira Press, Plymouth.

Court, D. and Abbas, R. (2013), "Whose Interview Is Is, Anyway? Methodological and Ethical Challenges of 
Insider-Outsider Research, Multiple Languages, and Dual-Researcher Cooperation", Qualitative Inquiry, Vol. 19 No. 6, pp. 480-488.

deGama, N., Elias, S.R.S.T.. and Peticca-Harris, A. (2019), “The good academic: re-imagining good research in organization and management", Qualitative Research in Organizations and Management: An International Journal , Vol. 14 No. 1, pp. 2-9.

Donnelly, P.F., Gabriel, Y. and Özkazanç-Pan, B. (2013), "Untold stories of the field and beyond: narrating chaos", Qualitative Research in Organizations and Management: An International Journal, Vol. 8 No. 1, pp. 4-15.

Edwards, R. and Mauthner, M. (2012), "Ethics and Feminist Research: Theory and Practice”, in Miller, T., Birch, M., Mauthner, M. and Jessop, J. (Eds.), Ethics in Qualitative Research, 2nd ed., SAGE Publications Ltd, London, pp. 14-28.

Eriksson, P. (2013), "Longitudinal autoethnography", in Hassett, M.E. and Paavilainen-Mäntymäki, E. (Eds.), Handbook of Longitudinal Research Methods in Organisation and Business Studies, Edward Elgar Publishing, Cheltenham.

Flyvbjerg, B. (2001), Making Social Science Matter: Why Social Inquiry Fails and How It Can Succeed Again, Cambridge University Press, Cambridge.

Gilmore, S. and Kenny, K. (2015), “Work-worlds colliding: Self-reflexivity, power and emotion in organizational ethnography", Human Relations, Vol. 68 No. 1, pp. 55-78.

Gioia, D.A. and Chittipeddi, K. (1991), "Sensemaking and Sensegiving in Strategic Change Initiation", Strategic Management Journal, Vol. 12 No. 6, pp. 433-448.

Gioia, D.A., Corley, K.G. and Hamilton, A.L. (2012), "Seeking Qualitative Rigor in Inductive Research: Notes on the Gioia Methodology", Organizational Research Methods, Vol. 16 No. 1, pp. 15-31. 
Gusterson, H. (1997), "Studying Up Revisited", PoLAR: Political and Legal Anthropology Review, Oxford, UK, Vol. 20 No. 1, pp. 114-119.

Hardy, C., Phillips, N. and Clegg, S. (2001), "Reflexivity in organization and management theory: A study of the production of the research 'subject'”, Human Relations, Vol. 54 No. 5, pp. 531-560.

Head, E. (2009), "The ethics and implications of paying participants in qualitative research", International Journal of Social Research Methodology, Vol. 12 No. 4, pp. 335-344.

Heins, V.M., Unrau, C. and Avram, K. (2018), “Gift-giving and reciprocity in global society: Introducing Marcel Mauss in international studies", Journal of International Political Theory, Vol. 14 No. 2, pp. $126-144$.

Järventie-Thesleff, R., Logemann, M., Piekkari, R. and Tienari, J. (2016), “Roles and identity work in 'athome' ethnography", Journal of Organizational Ethnography, Vol. 5 No. 3, pp. 235-257.

Kaptein, M. (2015), "The Effectiveness of Ethics Programs: The Role of Scope, Composition, and Sequence.", Journal of Business Ethics, Vol. 132 No. 2, pp. 415-431.

Koning, J. and Ooi, C. (2013), "Awkward encounters and ethnography", Qualitative Research in Organizations and Management: An International Journal, Vol. 8 No. 1, pp. 16-32.

Macdonald, S. and Hellgren, B. (2004), "Interviewing in International Business Research: Problems We Would Rather Not Talk About", in Welch, C. and Marschan-Piekkari, R. (Eds.), Handbook of Qualitative Research Methods for International Business, Cheltenham, pp. 264-281.

Malm, T. (2018), "Recognizing the practitioner-self: lessons from studying rock bands at-home", Journal of Organizational Ethnography, Vol. 7 No. 2, pp. 135-146.

Marcus, G.E. (1997), "The Uses of Complicity in the Changing Mise-en-Scène of Anthropological Fieldwork", Representations, Vol. Special is No. 59, pp. 85-108. 
Marschan-Piekkari, R., Welch, C., Penttinen, H. and Tahvanainen, M. (2004), "Interviewing in the Multinational Corporation: Challenges of the Organizational Context", in Welch, C. and MarschanPiekkari, R. (Eds.), Handbook of Qualitative Research Methods for International Business, Edward Elgar, Cheltenham, UK and Northampton, pp. 244-263.

Mauss, M. (2000), The Gift: Forms and Functions of Exchange in Archaic Societies, Spektrum, Copenhagen.

Michailova, S., Piekkari, R., Plakoyiannaki, E., Ritvala, T., Mihailova, I. and Salmi, A. (2014), "Breaking the silence about exiting fieldwork: a relational approach and its implications for theorizing", Academy of Management Review, Academy of Management, Vol. 39 No. 2, pp. 138-161.

Murphy, E. and Dingwall, R. (2001), "The Ethics of Ethnography", in Atkinson, P., Coffey, A., Delamont, S., Lofland, J. and Lofland, L. (Eds.), Handbook of Ethnography, SAGE Publications Ltd, London, pp. 339351.

Musambira, G., Collins, S., Brown, T. and Voss, K. (2012), "From \&quot;Publish or Perish\&quot; to \&quot;Grant or Perish\&quot;: Examining Grantsmanship in Communication and the Pressures on Communication Faculty to Procure External Funding for Research", Journalism \& Mass Communication Educator, Vol. 67 No. 3, pp. 234-251.

Natifu, B. (2016), “Multiple levels of 'knowing and being known', their affiliated capital, benefits and challenges", Journal of Organizational Ethnography, Vol. 5 No. 3, pp. 219-234.

Piekkari, R. and Tietze, S. (2016), “Doing research on power and politics in multinational corporations (MNCs): a methodological perspective", in Becker-Ritterspach, F., Blazejewski, S. and Dörrenbächer, C. Geppert, M. (Eds.), Micropolitics in the Multinational Corporation, , Cambridge University Press, Cambridge, pp. 208-240.

Pratt, M.G. (2009), “From the Editors: For the Lack of a Boilerplate: Tips on Writing up (And Reviewing) 
Qualitative Research", The Academy of Management Journal, Vol. 52 No. 5, pp. 856-862.

Rhoades, L. and Eisenberger, R. (2002), "Perceived Organizational Support: A Review of the Literature", Journal of Applied Psychology, Vol. 87 No. 4, pp. 698-714.

Srivastava, V.K. (1992), "Should Anthropologists Pay Their Respondents?", Anthropology Today, Vol. 8 No. 6, pp. 16-20.

Swartz, S. (2011), “'Going deep' and 'giving back': strategies for exceeding ethical expectations when researching amongst vulnerable youth", Qualitative Research, Vol. 11 No. 1, pp. 47-68.

Symon, G., Cassell, C. and Johnson, P. (2018), "Evaluative Practices in Qualitative Management Research: A Critical Review", International Journal of Management Reviews, Vol. 20, pp. 134-154.

Tracy, S.J. (2012), Qualitative Research Methods: Collecting Evidence, Crafting Analysis, Communicating Impact, United Kingdom: Wiley-Blackwell.

Tracy, S.T. (2010), “Qualitative Quality: Eight 'Big-Tent' Criteria for Excellent Qualitative Research”, Qualitative Inquiry, Vol. 16 No. 10, pp. 837-851.

Vincett, J. (2018), “Researcher self-care in organizational ethnography: Lessons from overcoming compassion fatigue", Journal of Organizational Ethnography, Vol. 7 No. 1, pp. 44-58.

Welch, C. and Piekkari, R. (2017), “How should we (not) judge the 'quality' of qualitative research? A reassessment of current evaluative criteria in International Business", Journal of World Business, Vol. 52, pp. $714-725$.

Wichmann-Hansen, G. and Herrmann, K.J. (2017), “Does external funding push doctoral supervisors to be more directive? A large-scale Danish study", Higher Education, Vol. 74 No. 2, pp. 357-376. 